\title{
MATHEMATICAL MODELING OF TEMPERATURE AND HEAT PROFILES IN PILOT REFRACTANCE WINDOW DRYING SYSTEM
}

\author{
B. M. A. Amer*
}

\section{$\underline{\text { ABSTRACT }}$}

The design of the Refractance Window (RW) drying system was based on a novel concept in which hot water is circulating beneath and in contact with a transparent plastic conveyor belt where a thin film of puree is to be dried. A mathematical model that accounts for heat and mass transfer, and temperature buildup was developed for the $R W$ pilot dryer. One set of equations was developed to predict temperatures of the Mylar plastic sheet and the product during the drying process. Another set of equations was developed to predict the heat requirements for drying of mango puree using the same system. This model was validated using the experimental results obtained at MCD Technologies, Inc., Tacoma, WA, USA. Good agreement was found among the temperatures obtained from experimental results and from the model. This model can be used to predict temperatures and heat profiles for the $R W$ dryer for drying mango puree as well as other fruits and vegetables purees.

\section{INTRODUCTION}

novel thin film high quality drying technique called Refractance Window (RW) was recently developed by American company Dcalled MCD Technologies, Inc., (Tacoma, Washington State) for producing dried products from liquid and semi-liquid foods. The company has since patented this drying system. This drying method is characterized by mild product temperature and short drying times. In the operation of a RW dryer, liquid or semi-liquid foods (e.g., eggs, and pureed fruits and vegetables) are applied in a thin film onto a plastic belt that moves over a hot water flume.

*Lec., Agric. Eng.; Fac. of Agric.; Cairo University-Egypt 
The Refractance Window drying system utilizes circulating hot water, usually at $95-97^{\circ} \mathrm{C}$ and at atmospheric pressure, to carry thermal energy to material to be dehydrated (Fig. 1). Thermal energy from circulating hot water is transferred to the wet product via a plastic interface that is relatively transparent to infrared radiation. Products, which include juice, purees, and suspensions, are spread on the transparent plastic conveyor belt that moves while its bottom surface is in contact with hot water circulating on shallow troughs. In the RW pilot dryer, the heated water is recycled and reused by electrical heating unit in water tank, thereby improving the thermal efficiency of the system. The use of hot water as the heat transfer medium and at temperatures just below boiling is a design feature that is unique to this drying method. The dried products are then moved over a cold water trough before being scrapped off the belt. The product is tempered as cold water circulates under the belt, which enables easy separation of the product from the belt by a scraper device.

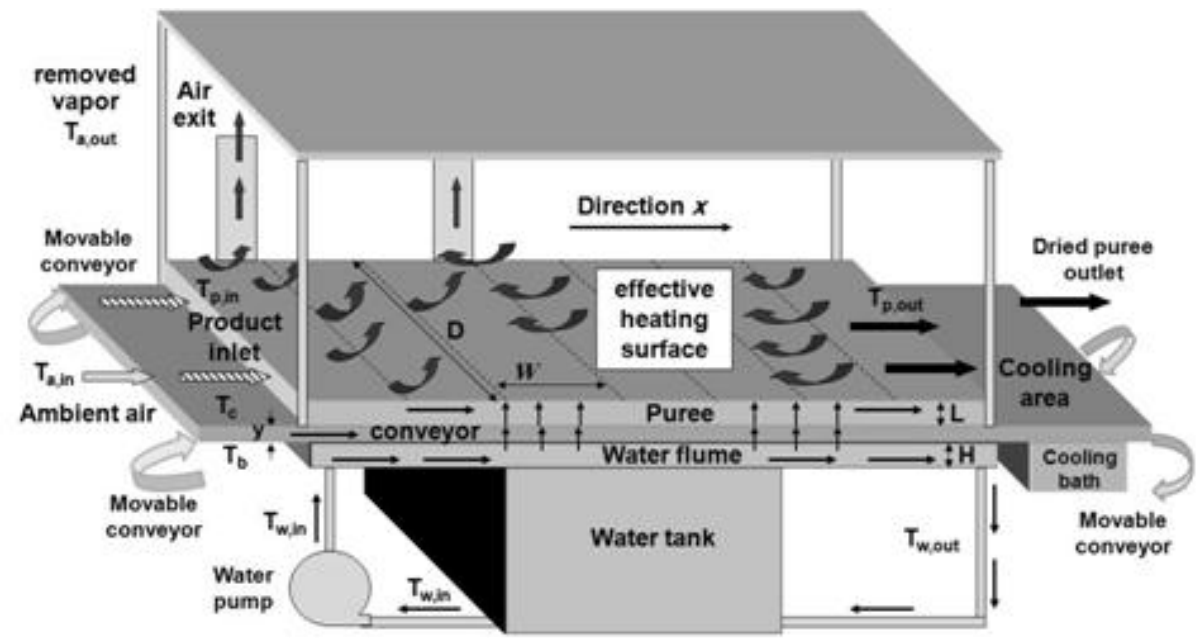

Fig.(1): Schematic diagram of (RW) drying system showing temperatures and heat transfer from the circulating hot water to the product.

Abonyi et al., (2002) reported that the superior quality retention capability demonstrated by RW drying is most likely due to the favorable combination of short drying times and relatively mild product temperatures. The rapid mass transfer from wet product and the resulting high vapor saturation above the product limits product-oxygen interaction 
and helps to maintain the quality of product as the residence time for RW drying of pureed asparagus from about $90 \%$ to $4 \%$ moisture content (wet basis) was only 4.5 min (Nindo et al., 2003).

The plastic sheet made from Mylars (DuPont Polyester Film Enterprise, Wilmington, DE) allows transmission of infrared energy with the wavelengths that match the absorption spectra of water. This infrared transmission is important because it enables rapid evaporation at low temperature and more than compensates for the low thermal conductivity of the plastic $(0.155 \mathrm{~W} / \mathrm{m} . \mathrm{K}$ compared to $15 \mathrm{~W} / \mathrm{m} . \mathrm{K}$ for stainless steel), all work together to facilitate rapid drying, (Smith, 1994) and Nindo et al. (2007a). Water has high absorption for infrared with wavelengths of 3.0, 4.7, 6.0, and $15.3 \mathrm{~mm}$, (Sandu, 1986).

According to Abonyi et al., (2002), the infrared transmission is stronger when the plastic interface is in intimate contact with water on one side and a moisture-laden material on the other side. When a pureed product with high moisture content is spread on top of the thin plastic conveyor, refraction at the plastic-puree interface is minimized, causing the radiant thermal energy to pass through the plastic into the product. Because of evaporative cooling, the product temperature does not reach the heating water temperature. The absorptivity of the puree is influenced by its thickness and moisture content, (Ratti and Mujumdar, 1995). Nindo and Tang (2007) reported that during RW drying, the three modes of heat transfer, namely conduction, convection, and radiation, are active. The process water is heated within an insulated tank and then circulated in shallow troughs to transfer thermal energy to the plastic conveyor. Since the plastic conveyor is very thin, it reaches the temperature of hot water flowing beneath it almost immediately. Thermal energy from the hot water is transmitted through the plastic conveyor by conduction and radiation; however the precise contribution of each of these modes of heat transfer still needs to be investigated. In addition, there were some initial trying (model) by Nindo et al. (2003 and 2004) to study the heat balance for the pilot and commercial types of RW systems. But, these trying were based on designs that used hot vapor as a heating medium and it did not predict the temperature of puree during the RW drying. Here, we report the development of a more sophisticated model of heat transfer in designs 
where electric heating elements are used. It is well established that the use of electric heating elements results in substantial improvement in heating efficiency.

The objectives of this study of the pilot dryer were (1) to investigate the product temperature and heat transfer in electricity-heated RW dryers, (2) to develop the initial model by Nindo et al. (2003 and 2004) to be more accurate and to predict the temperature of puree during the RW drying, and (3) to validate the predicted temperatures using experimental results.

\section{MATERIALS AND METHODS}

\section{A. Preparation of Mango Purees}

Frozen mango purees were imported from The Philippines. To reduce possible quality degradation, the mango purees for energy studies were transported to American company called MCD Technologies, Inc., (Tacoma, WA) for continued freezing. Mango puree was used as a model food in these studies because of its good film-forming ability. For the energy studies, the frozen purees were thawed in cold storage at $4^{\circ} \mathrm{C}$ for about $24 \mathrm{~h}$. The purees were then well mixed and allowed to condition at room temperature for 6 to $8 \mathrm{~h}$ before using in the experiments.

\section{B. Drying Experiments of Mango Purees by Pilot-Scale Dryer}

A $3 \mathrm{~m} \times 0.6 \mathrm{~m}$ pilot-scale RW dryer was used in these experiments. Appropriate engineering data were collected, including air velocity over the product, speed of conveyor, drying time, and temperatures for water, air, plastic conveyor and product. The experiments also provided information to validate predicted data, e.g. product temperatures along the length of plastic conveyor during the drying time.

The drying experiments were conducted with the belt moving and also with a stationary belt. It was observed in both cases that the product temperature did not reach the heating water temperature. This may be attributed to resistance to heat transfer and cooling that accompanies intense evaporation.

Changes in mango puree temperature with time and along the belt from the application end to the exit point were determined for the pilot-scale RW dryer. Purees for temperature determination were scraped off the belt 
at 8 points ( 7 sections) located $0.30 \mathrm{~m}$ apart. The surface temperature of puree was measured at the application point, within the drying section enclosed with a stainless steel hood (Fig. 1), and at the exit point for the dry purees. A precalibrated Raynger ST infrared thermometer (Raytek, Santa Cruz, CA) was used for temperature measurements. In the separate precalibration tests, the emissivity values were obtained by adjusting the infrared thermometer until the temperature reading matched that of the thermocouple. Other measurements of puree temperature change over time were made using the dryer with the Mylar belt in a stationary position. For this study, according to the primary experiments, mango puree was spread onto the belt in $0.6-0.8 \mathrm{~mm}$ (the best range) using a spreader bar, after the flume underneath it was filled with hot water.

\section{Theoretical Model}

This model was developed using a set of partial differential equations to describe the heat and mass transfer between the drying air and the product and also within a single layer of product during a small time increment. The following assumptions are made for simplifying it.

- There is an equal heat flow from the water flume perpendicular to the direction of plastic conveyor throughout the product heating area. Therefore, the temperature of the plastic conveyor is assumed to be constant at any product-heating area.

- Product flow and plastic conveyor are in the same direction.

-There is no heat flow from air, it only carried the removed moisture.

- The time for thermostat readjustment is proportional to the speed of the conveyor. As the speed increases, the time the thermostat takes to readjust to $97^{\circ} \mathrm{C}$ decreases, giving larger amounts of heat for drying.

- There are no chemical reactions.

\section{Mass transfer for Drying in the RW System:}

\subsection{Mass of water to be removed from total mass of the fresh puree:}

Moisture content of fresh fruit was determined by vacuum oven drying method (Sodha et al., 1987). The total mass of water to be removed from the total mass of the fresh fruit is: 
PROCESS ENGINEERING

$$
\mathrm{m}_{\mathrm{w}}=\mathrm{m}_{\mathrm{p}} \times\left[\frac{\mathrm{M}_{\mathrm{i}}-\mathrm{M}_{\mathrm{f}}}{100-\mathrm{M}_{\mathrm{f}}}\right]
$$

Where

$\mathrm{m}_{\mathrm{w}}$ removed mass of water from the total mass of fresh puree, $\left(\mathrm{kg}_{\mathrm{w}}\right)$

$\mathrm{m}_{\mathrm{p}} \quad$ mass of fresh puree at the beginning of drying process, $\left(\mathrm{kg}_{\mathrm{p}}\right)$

$\mathrm{M}_{\mathrm{i}}$ moisture content, wet basis, of fresh puree, (determined to be 83$87 \%)$.

$\mathrm{M}_{\mathrm{f}}$ final moisture content, wet basis, of puree, (determined to be 2-5\%).

While the mass of water to be removed from puree in one stage of plastic conveyor is:

$$
\mathrm{m}_{\mathrm{w}, \mathrm{s}}=\mathrm{m}_{\mathrm{p}, \mathrm{s}} \times\left[\frac{\mathrm{M}_{\mathrm{i}, \mathrm{s}}-\mathrm{M}_{\mathrm{f}, \mathrm{s}}}{100-\mathrm{M}_{\mathrm{f}, \mathrm{s}}}\right]
$$

Where:

s number of stages divided in the plastic conveyor, $(1,2,3, \ldots, 7)$.

$\mathrm{m}_{\mathrm{w}, \mathrm{s}}$ removed mass of water from puree at each stage of conveyor, $\left(\mathrm{kg}_{\mathrm{w}}\right)$

$\mathrm{m}_{\mathrm{p}, \mathrm{s}}$ mass of fresh puree at any time during drying process, $\left(\mathrm{kg}_{\mathrm{p}}\right)$.

$\mathrm{M}_{\mathrm{i}, \mathrm{s}}$ initial moisture content, wet basis, of puree at the stage, $(\%)$.

$\mathrm{M}_{\mathrm{f}, \mathrm{s}}$ final moisture content, wet basis, of puree at the end of stage, (\%).

\subsection{Rate of water to be removed from puree at any time (stage)} during drying process ${ }^{6} \mathrm{~m}^{\bullet}{ }_{\mathrm{m}, \mathrm{i}}$ "

$$
\mathrm{m}_{\mathrm{m}, \mathrm{s}}^{\bullet}=\mathrm{m}_{\mathrm{m}, \mathrm{s}} / \mathrm{t}_{\mathrm{s}}
$$

Where

$\mathrm{m}_{\mathrm{m}, \mathrm{s}}$ removed water from puree at any time (stage) during drying, $\left(\mathrm{kg}_{\mathrm{w}}\right)$

$\mathrm{t}_{\mathrm{s}} \quad$ time at the estimated value of moisture during drying process, (s).

\section{Energy Balance of Drying for the RW Drying System:}

Nindo et al (2004) found that in Refractance Window drying system, the most of losses occur through the bottom stainless-steel plate supporting the plastic conveyor.

These principles are considered in this account as well. The energy balance can be expressed in the following equation:

Thermal energy in water $=$ Heat used for RW drying + heat losses

or, $\quad Q_{w}=Q_{R}+Q_{L}$

- $Q_{w}$ thermal energy, can be defined as: 
Thermal energy supplied by water in the water tank and flume to keep its temperature around $96-97^{\circ} \mathrm{C}$ as a desired for the RW system.

- $Q_{R}$ is the heat transferred to puree or the heat required for the drying process and it can be further divided into two components:

1. Sensible heating of puree which is the energy needed to rise the product temperature to the desiring temperature for drying " $Q_{P}$ ".

2. Energy needed to evaporate the amount of moisture to be removed from the fresh fruit " $Q_{\text {evap }}$ ".

- $Q_{L}$ stands for heat losses and can be divided into:

1. Heat losses from the system by convection through water flume " $Q_{\text {conv, },(a-f)}$ " and to the air from puree surface " $Q_{c o n v,(a-p)} "$.

2 . Heat losses from the system by radiation through water flume " $Q_{\text {rad,f }}$ " and puree surface " $Q_{\text {rad, } p}$ ".

Figure 2, illustrates all the previous types of thermal energy transfer within the RW dryer.

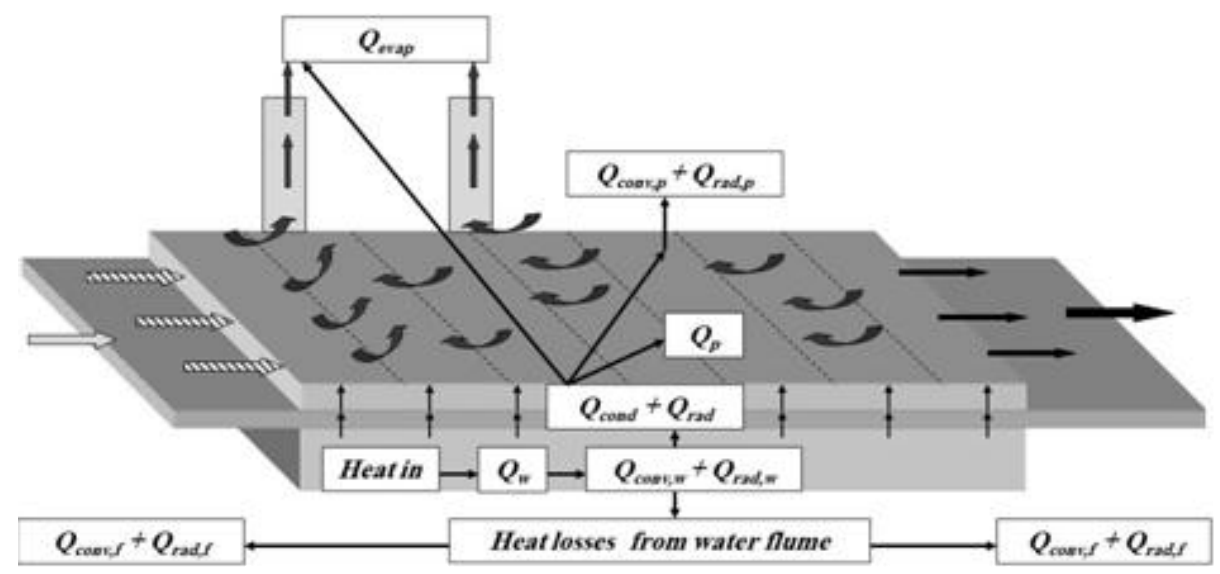

Fig. (2): Representation of thermal energy transfer within the RW dryer.

\subsection{Thermal energy supplied to water " $Q_{w}$ "}

This stage is concerned with raising the temperature of water before the puree over the belt starts the drying process. This transferred heat transfer will use:

1. The available energy to raise the temperature of tap water to the desired point $\left(96-97^{\circ} \mathrm{C}\right)$.

This available energy was used to raise the temperature of entering water to the heating tank from room temperature to the desired point $\left(96-97^{\circ} \mathrm{C}\right)$ 
for the Refractance Window drying system. This energy will not be used in the calculation of the model because it supplies the thermal energy to the water one time only to reach its study state required condition before the RW drying starts, then the heater was regulated to maintain water to do not fall below the set temperature. Therefore, it could be neglecting from these calculations.

2. The following supply of the thermal energy as useful energy for keeping the temperature of water at the desired point $\left(96-97^{\circ} \mathrm{C}\right)$, by applying the suitable thermostat.

$$
Q_{w}=\rho_{w} V^{\bullet} c_{p, w}\left(T_{w, \text { out }}-T_{w, \text { in }}\right)
$$

Where

$\rho_{w} \quad$ density of water, $\left(\mathrm{kg} / \mathrm{m}^{3}\right)$

$c_{p, w} \quad$ specific heat of water $(\mathrm{kJ} / \mathrm{kg} . \mathrm{K})$

$V_{w}^{\bullet} \quad$ rate of volume, $\left(\mathrm{m}^{3} / \mathrm{s}\right)$

$T_{w, \text { in }} \quad$ inlet water temperature from tank to water flume, $\left(97^{\circ} \mathrm{C}\right)$

$T_{w, \text { out }}$ outlet water temperature from water flume to water tank, $\left(96^{\circ} \mathrm{C}\right)$

The heat rate input inside the water transferred to the plastic conveyor's base consists of two components: convection and radiation. Therefore, to determine the temperature of the side in contact with the water, the following equation calculating the transferred heat through the water flume and the plastic conveyor's base should be used:

$$
Q_{w}=Q_{c o n v, w}+Q_{r a d, w}=\left[A_{c} h_{w}\left(T_{b}-T_{w, i n}\right)+A_{c} \delta \varepsilon_{c}\left(T^{4}{ }_{b}-T^{4}{ }_{w, i n}\right)\right]
$$

Where:

$A_{c}$ area of plastic conveyor $\left(\mathrm{m}^{2}\right)$

$h_{w}$ convective heat transfer coefficient for water under the plastic conveyor, $\left(\mathrm{W} / \mathrm{m}^{2} \cdot{ }^{\circ} \mathrm{C}\right)$

$T_{b}$ surface temperature of the conveyor in contact with water flume, $\left({ }^{\circ} \mathrm{C}\right)$

The heat transferred by radiation through the water flume and the plastic conveyor's base could be neglecting due to it is very small comparing to the heat by convection.

Because the water pump in the RW dryer was used to circulate water from the water tank to the water flume, the flow condition of the water during drying (whether laminar or turbulent) was determined by 
calculating the Reynolds Number "Re" and Nusselt number " $N u$ ", leading to the calculations of the convective heat transfer coefficient for water under the plastic conveyor " $h_{w}$ " using the following equations,

$$
\begin{aligned}
& \operatorname{Re}=\frac{u_{w} * D_{h}}{v_{w}} \\
& N u=\frac{h_{w} * D_{h}}{k_{w}}=0.664 \operatorname{Re}^{0.5} \operatorname{Pr}^{0.33} \quad \text { for } 0.6 \leq \operatorname{Pr} \leq 10 \\
& h_{w}=\frac{k^{*} N u}{D_{h}} \quad\left(\frac{W}{m^{2} .{ }^{\circ} C}\right)
\end{aligned}
$$

Where " $D_{h}$ " is the hydraulic width of water flume (m); and it could be calculated from the following equation according to Cengel, (2003), by using both of the actual width of water flume " $D=0.6 \mathrm{~m}$ " and its height " $H=0.03 \mathrm{~m}$ ",

$$
D_{h}=\frac{4 D^{*} H}{2(D+H)}
$$

Where:

Pr Prandtl number, non-dimensional ratio of the viscous boundary layer thickness to the thermal boundary layer thickness. (was taken as 1.9 for water, according to Cengel, 2003).

The mean water velocity in water flume " $u_{w}$ " was measured to be 0.037 $\mathrm{m} / \mathrm{s}$; and the mean water temperature, " $T_{w}$ " was $96-97^{\circ} \mathrm{C}$. At these mean values temperature of the boundary water, the thermal conductivity " $k$ " of water was found to be $0.67 \mathrm{~W} / \mathrm{m} . \mathrm{K}$, while the Prandtl Number was 1.9, and the kinematic viscosity of the water " $v_{w}$ " was $0.0003 \mathrm{~m}^{2} / \mathrm{s}$, according to Cengel, (2003).

For internal flow, Reynolds Number $\operatorname{Re}=6772.76$. Since $\operatorname{Re}>2300$, therefore the water in the flume is in the transitional or turbulent regime and the convective heat transfer coefficient " $h_{w}$ " may be obtained from the general turbulent flow relationship. The calculated value of it depending on the previous equations was found to be $386.94 \mathrm{~W} / \mathrm{m}^{2} . \mathrm{K}$.

\subsection{Heat lost by convection from the water flume " $Q_{c o n v,(a-f) "}$}

Since no air blower was used below the bottom plate of water flume, natural convection conditions prevailed as confirmed by calculations from 
the following equation. By determining the Rayleigh Number $R a_{L}<10^{10}$ for natural convection, the heat transfer coefficient " $h_{a}$ " between the air and bottom plate of the water flume was calculated (Incropera and DeWitt, 1996).

$$
N u=\frac{h_{a, o u t} * d}{k_{F}}=0.27 \mathrm{Ra}^{0.25}
$$

and, $\quad R a=\frac{g \beta\left(T_{F, \text { out }}-T_{a, \text { in }}\right) * d^{3}}{v \alpha}$

Where " $g$ " is acceleration due to gravity $\left(9.81 \mathrm{~m} / \mathrm{s}^{2}\right), " \beta$ " is the coefficient of volumetric thermal expansion of air $\left(\mathrm{K}^{-1}\right)$, " $d$ " is characteristic length $(\mathrm{m})$, " $v$ " is kinematic viscosity of air $\left(\mathrm{m}^{2} / \mathrm{s}\right)$, " $\alpha$ " is thermal diffusivity of air $\left(\mathrm{m}^{2} / \mathrm{s}\right)$, water flume bottom surface temperature " $T_{f, \text { out }}$ " was measured to be $\left(47^{\circ} \mathrm{C}=320 \mathrm{~K}\right)$, while " $T_{a, \text { out }}$ " was the surrounding air temperature $\left(20^{\circ} \mathrm{C}=293 \mathrm{~K}\right)$. Therefore, $h_{a, \text { out }}=1.75$ $\mathrm{W} / \mathrm{m}^{2} . \mathrm{K}$; and the heat loss below the bottom water flume plate was obtained from:

$$
Q_{\text {conv },(a-f)}=A_{f} h_{a, \text { out }}\left(T_{f, \text { out }}-T_{a, \text { out }}\right)
$$

Where:

$A_{f}$ contact area between ambient air and water flume outside surface $\left(\mathrm{m}^{2}\right)$

$T_{f \text {,out }}$ water flume bottom surface temperature

\subsection{Heat lost by radiation from the water flume " $Q_{\text {rad, }}$ "}

Some thermal radiation losses arise from the heated dryer surfaces, especially the bottom steel surface and also from the surface of the puree being dried. The radiant heat loss is estimated using equation (14). Radiant heat losses were small because of the low surface temperatures involved. The endless plastic belt that moved close to the surface of bottom steel plate also minimized the heat losses.

$$
Q_{\text {rad, } f}=A_{f} \varepsilon_{f} F_{c-d} \delta\left(\left(T_{f, \text { out }}\right)^{4}-\left(T_{a, \text { out }}\right)^{4}\right)
$$

Where:

$\varepsilon_{f} \quad$ surface emissivity (taken as 0.22 for steel of water flume)

$F_{c-d}$ plastic conveyor surface to dryer wall view factor is nearly 1.0 (Incropera and DeWitt 1996).

Therefore, heat loss by radiation from the puree surface and from the bottom steel plate is very small. 


\subsection{Heat lost by convection to the air from puree surface " $Q_{c o n v,(a-p)}$ "}

A centrifugal fan located on the roof of the dryer building was used to exhaust the moisture-laden air from the dryer. The flow condition of the air over the puree during drying (whether laminar or turbulent) was determined also by calculating the Reynolds Number and Nusselt number, then by determining the convective heat transfer coefficient for air over puree surface " $h_{a, \text { in }}$ " using the equations 7 to 9 .

The actual product temperature during RW drying has been reported to be between $70^{\circ} \mathrm{C}$ and $80^{\circ} \mathrm{C}$ (Abonyi et al., 2002). However, in this study, the measured product temperature during RW drying ranged between 64 and $86^{\circ} \mathrm{C}$ for the two studied speeds $0.0065 \mathrm{~m} / \mathrm{s}$ and $0.0078 \mathrm{~m} / \mathrm{s}$ for belt (the best values of belt speed according to the primary experiments). The mean of measured product temperature " $T_{p}$ " was considered individually for each different speed of conveyor, which were $78^{\circ} \mathrm{C}$ for $0.0065 \mathrm{~m} / \mathrm{s}$ and $75^{\circ} \mathrm{C}$ for $0.0078 \mathrm{~m} / \mathrm{s}$.

The mean measured air velocity " $u_{a}$ " over the product was $0.92 \mathrm{~m} / \mathrm{s}$; and the mean ambient air temperature was measured to be $20^{\circ} \mathrm{C}$. However, the mean temperature of the boundary air coming into the hood over the product " $T_{a, i n}$ " was taken as $58^{\circ} \mathrm{C}$, which was calculated from the mean temperature of the measured ambient air " $T_{\text {ambient }}$ ", the measured water temperature in water flume " $T_{w}$ " was equal $96-97^{\circ} \mathrm{C}$. At this mean temperature of the boundary air, the thermal conductivity " $k$ " of air was determined as $0.0287 \mathrm{~W} / \mathrm{m} .{ }^{\circ} \mathrm{C}$, the Prandtl Number was 0.709 , and the kinematic viscosity of the air " $v_{a}$ " was $18.8 \times 10^{-6} \mathrm{~m}^{2} / \mathrm{s}$ according to Incropera and DeWitt (1996). " $D$ " is the width of belt (m), the calculated Reynolds Number $R e=29489$. Since $R e<5 \times 10^{5}$, the air flow was laminar above the puree surface. In this case, the convective heat transfer coefficient " $h_{a, i n}$ " between the air and the food may be obtained from the general laminar flow relationship. The calculated value of it depending on the previous equations was equal $4.8 \mathrm{~W} / \mathrm{m}^{2} .{ }^{\circ} \mathrm{C}$, and the heat loss to the air from product surface was obtained from:

$$
Q_{\text {conv, },(a-p)}=A_{c} h_{a, i n}\left(T_{p}-T_{a, i n}\right)
$$

\subsection{Heat lost by radiation from the puree surface " $Q_{\text {rad, },}$ "

$$
Q_{\text {rad, } p}=A_{c} \varepsilon_{p} \delta F_{c-d}\left(T_{p}^{A}-T_{a, i n}^{A}\right)
$$


PROCESS ENGINEERING

Where: $\varepsilon_{p}$ surface emissivity, (taken as 0.95 for puree)

\subsection{Heat required for the drying process " $Q_{R}$ "}

1. Sensible Heating of Puree " $Q_{p}$ "

It is the energy needed to rise the product temperature to the desiring temperature for drying,

$$
Q_{p}=m_{p}^{\bullet} c_{p} \Delta T_{p}=\rho_{p} V_{p}^{\bullet} c_{p} \Delta T_{p}=\rho_{p} u_{c} A_{s} c_{p}\left(T_{p, \text { out }}-T_{p, \text { in }}\right)
$$

Where:

$A_{s}$ area of each section for plastic conveyor, $\left(=0.183 \mathrm{~m}^{2}\right)$.

$c_{p}$ specific heat of product, (taken as $3.9 \mathrm{~kJ} / \mathrm{kg} .{ }^{\circ} \mathrm{C}$, (Rahman 1995)

$\rho_{p}$ density of product, (determined to be 1060 to $1100 \mathrm{~kg} / \mathrm{m}^{3}$ for mango puree).

$T_{p, \text { in }}$ inlet puree temperature to one of heating section over the belt, $\left({ }^{\circ} \mathrm{C}\right)$

$T_{p, \text { out }}$ outlet puree temperature from one of heating section over belt, $\left({ }^{\circ} \mathrm{C}\right)$

2. Energy needed to evaporate the moisture from the fresh puree " $Q_{\text {evap }}$ ".

$$
Q_{\text {evap }}=m_{w} \lambda_{w}
$$

Where:

$\lambda_{w}$ Latent heat of water vaporization, (2300 kJ/kg, Cengel, 2003).

\section{Temperature Determination during RW Drying}

\subsection{Temperature of drying plastic conveyor surface:}

Since the plastic sheet is very thin, it almost immediately comes into equilibrium with the temperature of water flowing beneath it. The plastic sheet transmits the net energy reaching it from the hot water through conduction and radiation. The proportions of energy conducted or radiated depend on the relative resistances provided by the plastic to these two modes of heat transfer (Nindo et al., 2006). Therefore, to determine the temperature of the upper surface for the plastic conveyor from the side in contact with puree " $T_{c}$ ", heat transfer through the plastic conveyor by conduction " $Q_{\text {cond,c }}$ " and by radiation " $Q_{\text {rad }, c}$ " could be considered through the thickness of plastic conveyor in the direction from the base till its surface, since:

$$
\begin{gathered}
Q_{w}=Q_{c o n v, w}+Q_{\text {rad }, w}=\left[\left(Q_{\text {cond }, c}+Q_{\text {rad }, c}\right)+\left(Q_{\text {conv },(a-f)}+Q_{\text {rad }, f}\right)\right] \\
\text { then, } \quad Q_{\text {cond }, c}+Q_{\text {rad, }, c}=\left[Q_{w}-\left(Q_{\text {conv },(a-f)}+Q_{\text {rad }, f}\right)\right]
\end{gathered}
$$


However, trial and error method could be used to get " $T_{c}$ ", also the term of radiation " $Q_{\text {rad,c }}$ " could be neglected because its value is very small, then " $T_{c}$ " could be easily be obtained from the term of conduction through the plastic conveyor " $Q_{\text {cond,c }}$ " only using the following equation,

$$
T_{c}=\left[-\left(Q_{c o n d, c} * y\right) /\left(A_{c} k_{c}\right)\right]+\left(T_{b}\right)
$$

Where

$y$ thickness of the plastic conveyor, (m).

\subsection{Temperature of puree on drying plastic conveyor:}

In order to determine the temperature of the puree during the RW drying in this stage, the puree that spread over the belt was dived into small sections along the direction of $x$. In each section, it is assumed that the puree surface temperature is uniform. Therefore, the predict product temperature can be calculated by the following energy balance equation,

$$
Q_{\text {cond }, c}=Q_{\text {cond }, p}=\left[\left(Q_{\text {conv },(a-f)}+Q_{\text {rad }, p}\right)+\left(Q_{\text {evap }}+Q_{p}\right)\right]
$$

then,

$$
\begin{aligned}
& Q_{p}=\left[Q_{\text {cond }, c}-\left(Q_{\text {conv },(a-f)}+Q_{\text {rad }, p}+Q_{\text {eva }}\right)\right] \\
& T_{p, \text { out }}=\left[\left(Q_{p} /\left(\rho_{p} V_{p} c_{p}\right)\right)+\left(T_{p, \text { in }}\right)\right]
\end{aligned}
$$

\section{Heat Efficiency for Refractance Window Pilot Dryer " $\eta$ "}

The heat efficiency for RW pilot dryer was calculated by using both the useful heat for the drying process and the supplemented heat to the product over the plastic conveyor sheet, as the following equation,

$$
\eta=\frac{\text { useful heat }}{\text { supplemented heat }}=\frac{Q_{\text {evap }}+Q_{p}}{Q_{w}}
$$

\section{RESULTS AND DISCUSSION}

\section{A. Energy Consumption in Refractance Window Drying}

The evaporation of water from the product at the air-puree interface constitutes a major part of energy consumption in RW drying. To determine the thermal efficiency of RW dryer, heat balance was determined by measuring the temperatures of the heating water and the product at various points. Since heating water from the dryer flows back into a tank and is reheated, RW drying demonstrates very small amount of heat losses when compared with drying heat requirements. The summary for energy gain in the RW dryer with other consumption and losses for one batch of fresh mango puree at constant distance $2.13 \mathrm{~m}$ of the plastic conveyor, at two different velocities " $u_{c}$ ", is shown in Table 1 . 
Table (1): Summary of energy gain in the RW dryer with other consumption and losses for one batch of fresh mango puree at constant distance $2.13 \mathrm{~m}$ of the plastic conveyor.

\begin{tabular}{|c|c|c|c|c|c|c|c|c|c|}
\hline $\begin{array}{c}u_{c} \\
(\mathrm{~m} / \mathrm{s})\end{array}$ & $\begin{array}{c}\text { Drying } \\
\text { time } \\
(\mathrm{min})\end{array}$ & $\begin{array}{c}m_{p} \\
\left(\mathrm{~kg}_{\mathrm{p}}\right)\end{array}$ & $\begin{array}{c}m_{p}^{\bullet} \\
\left(\mathrm{kg}_{\mathrm{p}} / \mathrm{s}\right)\end{array}$ & $\begin{array}{c}Q_{w} \\
(\mathrm{~kW})\end{array}$ & $\begin{array}{c}Q_{\text {cond,c }} \\
(\mathrm{kW})\end{array}$ & $\begin{array}{c}Q_{\text {evap }} \\
(\mathrm{kW})\end{array}$ & $\begin{array}{c}Q_{p} \\
(\mathrm{~kW})\end{array}$ & $\begin{array}{c}Q_{\text {rad, } p} \\
(\mathrm{~kW})\end{array}$ & $\begin{array}{c}Q_{\text {conv }, p} \\
(\mathrm{~kW})\end{array}$ \\
\hline 0.0065 & 5.47 & 0.45 & 0.0012 & 2.28 & 2.14 & 1.05 & 0.74 & 0.23 & 0.12 \\
\hline 0.0078 & 4.56 & 0.44 & 0.0014 & 2.28 & 2.14 & 1.19 & 0.68 & 0.17 & 0.10 \\
\hline
\end{tabular}

Thermal energy from the puree to the ambient air is transferred primarily by convection and through evaporative cooling of the food material. This evaporation is very intense and constitutes a major part of energy consumption in RW drying. In the last stage of RW drying, when the product is almost dry, heat transfer by conduction becomes predominant and the rate of heat transfer to the product slows as the product dries further. The cooling section at the discharge end of the RW dryer is intended to reduce the product temperature, preferably to below the glass transition temperature of the product, to facilitate product removal.

However the main source of heat gain rate in the calculations was " $Q_{w}$ " which was obtained in equation (6) and it was $3.75 \mathrm{~kW}$ for $0.418 \mathrm{~kg}$ of fresh mango puree at $0.0065 \mathrm{~m} / \mathrm{s}$ and $4.21 \mathrm{~kW}$ for $0.338 \mathrm{~kg}$ of fresh puree at $0.0078 \mathrm{~m} / \mathrm{s}$. There is some loss from the water flume and the rest heat that goes through the plastic conveyor surface to puree " $Q_{\text {cond, },}$ " is 3.54 and $4.01 \mathrm{~kW}$ for $0.0065 \mathrm{~m} / \mathrm{s}$ and $0.0078 \mathrm{~m} / \mathrm{s}$ respectively.

Table 1 above illustrates that there is a small amount of heat loss that is equal to $0.21 \mathrm{~kW}$ from the bottom of water flume by convection and radiation which could be noticed from the difference between the value of input heat by water " $Q_{w}$ " and the heat gain through the plastic conveyor by conduction " $Q_{\text {cond }, c}$ ".

It also showed that the major heat required by RW drying is evaporation heat followed by sensible heat to raise the temperature of the product. Additionally, the major heat loss was from radiation, followed by the convection. The mean percentage of heat loss by radiation was around $18 \%$ from the heat evaporation and around $28 \%$ from heat sensible, respectively, whereas the percentage of heat loss by convection was 
around $10 \%$ from the heat evaporation and $16 \%$ from heat sensible, respectively.

In the case of RW system, the product thickness and consistency at deposition are very critical to the drying process. The product must spread thinly and adhere uniformly on the conveyor belt for the drying to be effective. Based on the latent heat of vaporization of water of about 2300 $\mathrm{kJ} / \mathrm{kg}$, thermal efficiency of RW drying was $52-77 \%$, when the product temperature was $60-70^{\circ} \mathrm{C}$ only (Nindo and Tang, 2007). This study of RW drying demonstrates very good thermal efficiency (equation, 23). Using the data in the previous table, the heat efficiency of the RW pilot dryer is determined to be $78-82 \%$, when the mean product temperature increased to $70-80^{\circ} \mathrm{C}$.

\section{B. Effect of Process Water and Product Temperature on RW Drying}

Nindo et al., (2007,b), reported that proper control of temperature of circulating water, is crucial for smooth operation and for improvement of system throughput and for retention of heat-sensitive compounds in juice. If the process water temperature comes close to boiling point, vapor will fill the water-plastic side of the evaporator's heat exchange area and distort the flexible evaporation surface causing a reduction in the transfer of thermal energy to the liquid product.

They also mentioned that when the process water temperature in a pilot RW dryer was increased from 85 to $95^{\circ} \mathrm{C}$, corresponding to product temperature increase from 55.5 to $59^{\circ} \mathrm{C}$, around $16 \%$ increase in the evaporation rate from 26.8 to $31.1 \mathrm{~kg} / \mathrm{h}$ was observed. The cyclic rise and fall in product temperature profile was not experienced in the pilot-scale evaporator because it was operated continuously with juice moving in and out of one tank. The reason for the big decrease in evaporation rate during the drying of mango puree in this study $(\approx 5 \mathrm{~kg} / \mathrm{h})$ could be due to the thicker thickness 6-7 mm when comparing with $1 \mathrm{~mm}$ for strawberries juice. It could be also referred to the difference in density between the pureed mango and strawberries juice, because the higher value in density for mango puree decreased the evaporation rate.

In addition, there was deference between the moisture content and the physical properties for the two types of fruit puree. 
The summary for temperature values which were measured during RW drying by pilot dryer for mango puree in this study could be obtained in table 2 .

Table (2): Summary for measured temperature values during $R W$ by pilot dryer for mango puree

\begin{tabular}{|l|c|}
\hline \multicolumn{1}{|c|}{ Item } & Value \\
\hline Temperature of water after heating in water tank, $T_{w}$ & $96-97^{\circ} \mathrm{C}$ \\
\hline Temperature of base of conveyor connecting with water, $T_{b}$ & $93-94^{\circ} \mathrm{C}$ \\
\hline Temperature of conveyor surface connecting with puree, $T_{c}$ & $91-92^{\circ} \mathrm{C}$ \\
\hline Max temperature of puree at effective drying area, $T_{P}$ & $84-86^{\circ} \mathrm{C}$ \\
\hline Temperature of ambient air, $T_{a, i n}$ & $18-22^{\circ} \mathrm{C}$ \\
\hline Temperature of puree at the beginning of drying, $T_{P 1}$ & $15-17^{\circ} \mathrm{C}$ \\
\hline Temperature of puree at the end point of belt after cooling, $T_{P 2}$ & $22-24^{\circ} \mathrm{C}$ \\
\hline Temperature of air at the exit from RW pilot dryer, $T_{a, o u t}$ & $23-26^{\circ} \mathrm{C}$ \\
\hline
\end{tabular}

These data showed that the water temperature was $97^{\circ} \mathrm{C}$ and there is a thermostat opened when its temperature decreased to be $96^{\circ} \mathrm{C}$ due to the heat losses during the drying process. In addition, using $2 \mathrm{~mm}$ as the thickness of the plastic conveyor " $y$ " and the thermal conductivity " $k_{c}$ " $0.155 \mathrm{~W} / \mathrm{m} . \mathrm{K}$ (Abonyi et al., 2002), the predicted value of temperature for plastic conveyor base side immerged in water was $93.88{ }^{\circ} \mathrm{C}$ which is close the mean measured value $94^{\circ} \mathrm{C}$.

\section{Experimental Validation for Predicting Belt and Puree Temperatures during RW Drying by Mathematical Model}

A set of equations basis on heat and mass transfer was developed to predict Mylar plastic sheet and product temperatures over it.

Figure 3 shows the results of the experimental data for empty plastic conveyor in cases of no belt movement and belt moving with $0.0065 \mathrm{~m} / \mathrm{s}$.

There was a very small difference between the measured temperatures in the two cases, and the measure temperatures were ranged between 91 and $93^{\circ} \mathrm{C}$. 


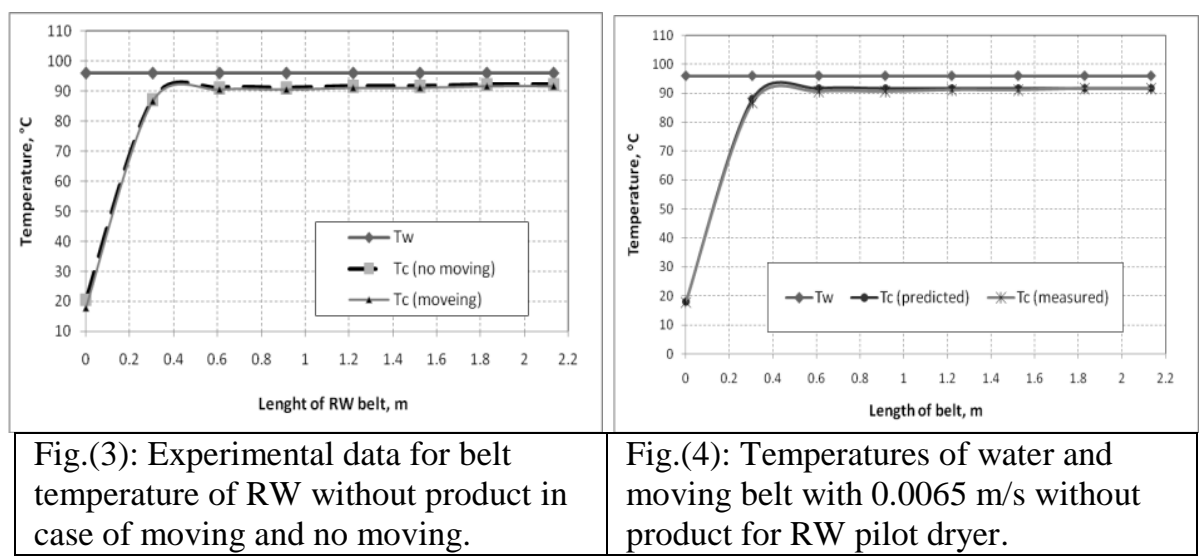

The difference between the water temperature $\left(96^{\circ} \mathrm{C}\right)$ and the mean temperature of surface plastic conveyor $\left(92^{\circ} \mathrm{C}\right)$ comes from the losses from the bottom of stainless-steel.

Figure 4 shows highly significant correlation $(P<0.05)$ was observed between the measured temperatures by experiments and the predicted temperatures by the mathematical model for moving belt with $0.0065 \mathrm{~m} / \mathrm{s}$ without product for RW pilot dryer.

Figure 5 shows a very good linear relationship obtained between the predicted temperatures of belt surface by the mathematical model and the measured temperature of belt surface by experiments.

It is likely that during the initial heating period immediately after the puree was applied to the drying belt, the large temperature difference between the puree and drying belt resulted in a rapid rise in puree temperature. After the puree reached an appropriate temperature, a thermal balance was established between the heat transfer from the circulating water to the puree surface and the removal of thermal energy due to surface moisture evaporation. These results were in agreement with the results obtained by Nindo et al. (2007a).

This process created evaporative cooling. After most of the moisture was removed at about 1.5-2 min of drying (Fig. 6), the evaporative cooling was reduced significantly due to much slowed moisture migration, and as a result, the puree temperature started to increase again.

Figure 6 shows the results of the experimental data for mango puree using two speeds for the belt and with puree over it in each case. 


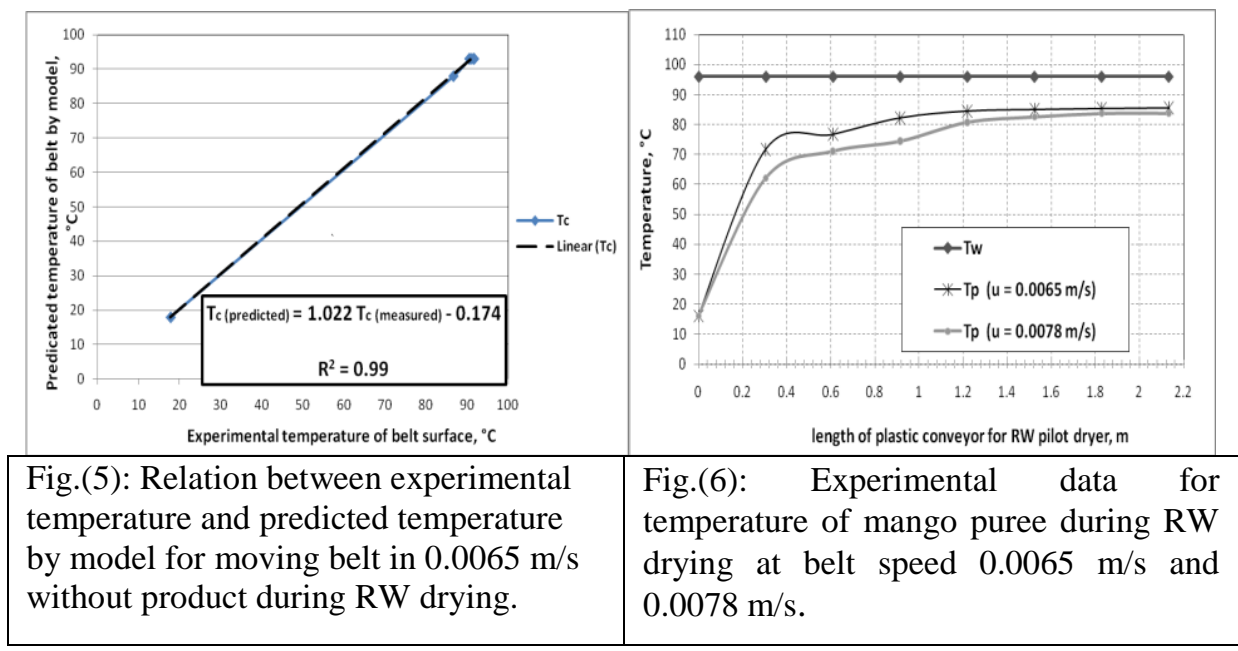

When the pilot scale dryer was used to study the puree temperature-time history, the profiles presented in figures 7 and 8 were established. The readings were taken with the stationary belt to ensure good contact between puree and thermocouples. The mean circulating water temperature was $96^{\circ} \mathrm{C}$. The measurement was made beyond 4.5 to 5.5 min for velocity of plastic conveyor of 0.0065 and $0.0078 \mathrm{~m} / \mathrm{s}$, respectively, to evaluate puree temperature changes over an extended drying period.

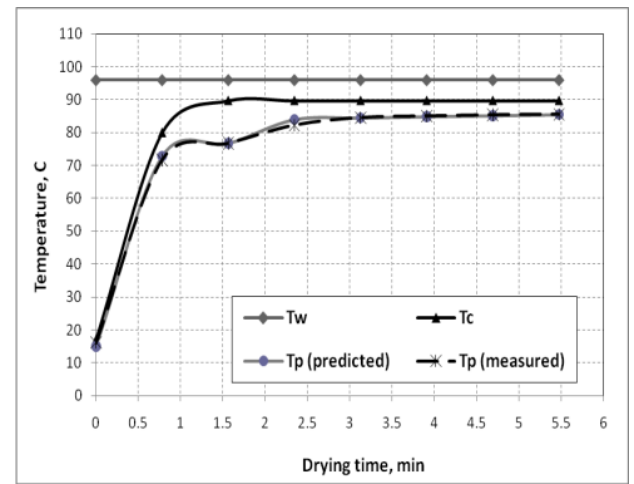

Fig. (7): Relation between temperature and time of moving belt with $0.0065 \mathrm{~m} / \mathrm{s}$ covered by mango puree in RW drying.

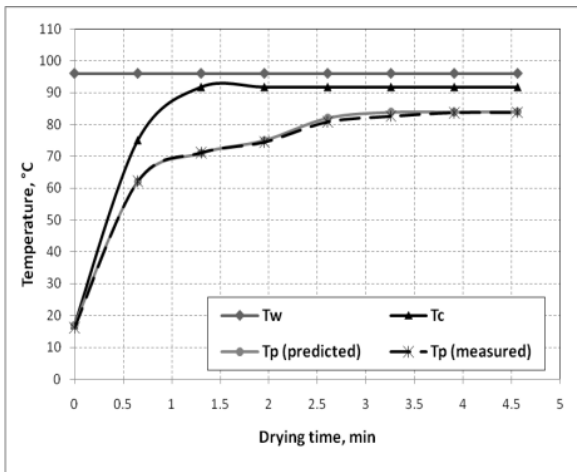

Fig.(8): Relation between temperature and time of moving belt with $0.0078 \mathrm{~m} / \mathrm{s}$ covered by mango puree in RW drying.

There was a rapid increase in puree temperature at the beginning of the drying after which it remained nearly constant at about $10^{\circ} \mathrm{C}$ below that of the circulating water temperature. Towards the end of the drying, puree 
temperature increased again to approach the circulating water temperature.

To validate the mathematical model for predicting the product temperature during the drying period with the experimental results during the belt movement, using two speeds for belt, 0.0065 and $0.0078 \mathrm{~m} / \mathrm{s}$ as presented in figures 7 and 8, respectively, which showed the relation between temperature and length of moving belt coved by mango puree during RW drying. A good agreement was found was observed $(P<0.05)$ between the expected temperature for mango puree during the drying section above the belt of RW pilot dryer and the measured data.

A linear relationship between the predicted temperatures of puree by mathematical model and the measured temperature of puree by experiments could be also determined as shown in Fig. 9 and Fig. 10 respectively.

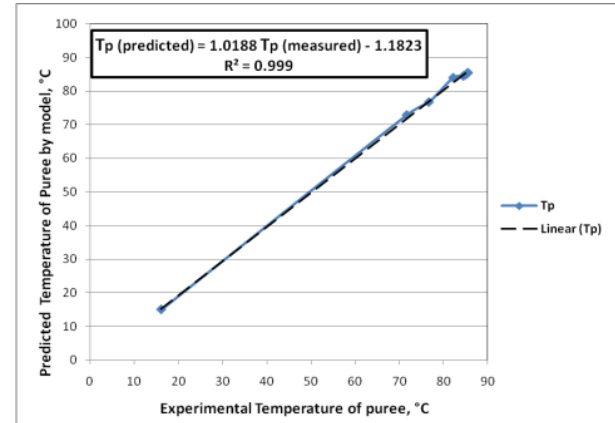

Fig. (9): Relation between drying time and predicted temperature by model for moving belt at $0.0065 \mathrm{~m} / \mathrm{s}$ with product (mango puree) during RW drying.

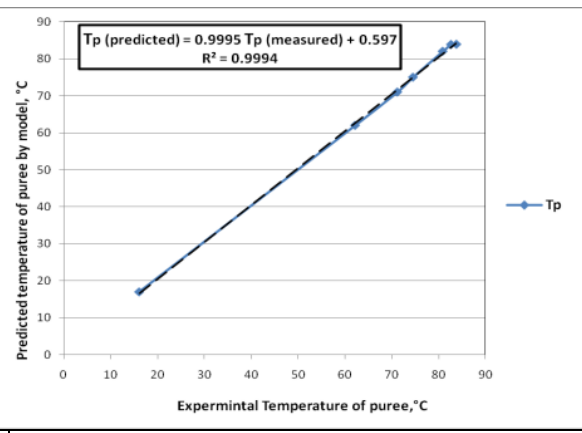

Fig. (10): Relation between drying time and predicted temperature by model for moving belt at $0.0078 \mathrm{~m} / \mathrm{s}$ with product (mango puree) during RW drying.

\section{CONCLUSION}

A model was developed to express mathematically the RW pilot dryer using mango puree. The model was physically based taking into account the heat transfer in it. One set of equations was developed to predict Mylar plastic sheet. In addition, it can predict the product temperatures during drying over any section from the plastic belt as the following: $T_{p, \text { out }}=\left[\left(Q_{p} /\left(\rho_{p} V_{p} c_{p}\right)\right)+\left(T_{p, \text { in }}\right)\right]$.

Another set of equations was developed to predict the heat requirement for air and drying of mango puree in the dryer. Two speeds $(0.0065$ and 
$0.0078 \mathrm{~m} / \mathrm{s}$ ) for the plastic conveyor of RW pilot dryer were tested. Good agreements were found between experimental and simulated plastic sheet and product temperatures. However, the predicted value of temperature for plastic conveyor base side immerged in water was $93.9^{\circ} \mathrm{C}$ which is close to the mean measured value $94^{\circ} \mathrm{C}$. There was a very small difference between the measured temperatures in the two cases, and the measured temperatures were ranged between 91 and $93^{\circ} \mathrm{C}$. The difference between the water temperature $\left(96^{\circ} \mathrm{C}\right)$ and the mean temperature of surface plastic conveyor $\left(92^{\circ} \mathrm{C}\right)$ was due to the losses from the bottom of stain-steal. The temperature of the puree over plastic conveyor during the short drying period in the RW pilot dryer ranged from 72 to $86^{\circ} \mathrm{C}$ for $0.0065 \mathrm{~m} / \mathrm{s}$ and from 64 to $84^{\circ} \mathrm{C}$ for $0.0078 \mathrm{~m} / \mathrm{s}$.

\section{RECOMMANDITIONS}

1. This mathematical model could be used with a good accuracy to predict the temperature of Mylar plastic sheet and temperature of other juices and purees during drying at the Pilot unit of RW system.

\section{REFERENCES}

Abonyi, B. I.; Feng, H.; Tang, J.; Edwards, C. G.; Mattinson, D. S. and Fellman, J. K. (2002). Quality retention in strawberry and carrot purees dried with Refractance Window System. Journal of Food Science, 67, 1051-1056.

Cengel, Y. A. (2003). Heat Transfer: A Practical Approach, $2^{\text {nd }}$ ed., McGraw-Hill.

Incropera, F. P. and DeWitt, D. P. (1996). Introduction to Heat Transfer, pp. 368, 460-463, 685, John Wiley \& Sons, New York.

Nindo, C. I.; Wang, S. W.; Tang, J. and Powers, J. R. (2003). Evaluation of drying technologies for retention of physical and chemical quality of green asparagus (Asparagus officinalis L.). Journal of Food Science and Technology (LWT), 36, 507-516.

Nindo, C. I.; Tang, J.; Powers, J. R. and Bolland, K. (2004). Energy consumption during Refractance Window evaporation of selected berry juices. International Journal of Energy Research, 28, 10891100 . 
Nindo, C. I.; Tang, J.; Cakir, E. and Powers, J. R. (2006). Potential of Refractance Window $^{\oplus}$ (RW ${ }^{\mathrm{TM}}$ ) Technology for Value Added Processing of Fruits and Vegetables in Developing Countries. An ASABE Meeting Presentation. Paper Number: 068064

Nindo, C. I. and Tang, J. (2007). Refractance Window Dehydration Technology: A Novel Contact Drying Method. Drying Technology, 25: $37-48$.

Nindo, C. I.; Feng, H.; Shen, G. Q.; Tang, J. and Kang, D. H. (2007a). Energy utilization and microbial reduction in a new film drying system. Journal of Food Processing and Preservation, 27 (2): 117 136.

Nindo, C. I.; Powers, J. R. and Tang, J. (2007b). Influence of Refractance Window evaporation on quality of juices from small fruits. LWT 40, 1000-1007.

Rahman, S. (1995). Food Properties Handbook, CRC Press LLC, Boca Raton, Florida.

Ratti, C. and Mujumdar, A. S. (1995). Infrared drying. In Handbook of Industrial Drying; Mujumdar, A.S., Ed.; Marcel Dekker: New York, 567-588.

Sandu, C. (1986). Infrared radiative drying in food engineering: A process analysis. Biotechnology Progress, 2, 109-119.

Smith, T. M. (1994). Heat transfer dynamics. TAPPI Journal, 77, 239-245.

Sodha, M. S.; Bansal, N. K.; Kumar, A.; Bansal, P. K. and Malik, M. A. S. (1987). Solar Crop Drying. CRC Press, Inc. Boca Raton, Florida.

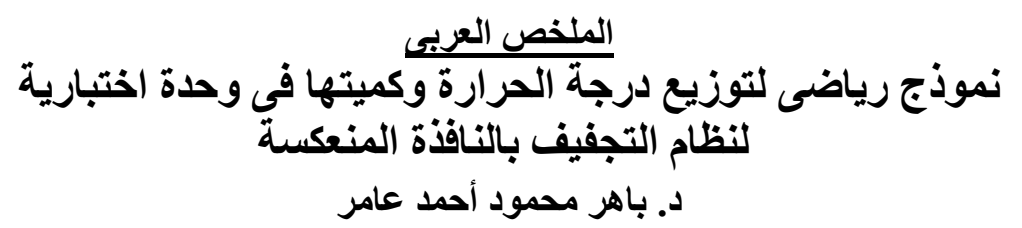

يعتبر نظام التجفيف بالنافذة المنعكسة من الطرق الجديدة المبتكرة لتجفيف السو ائل والمحاليل

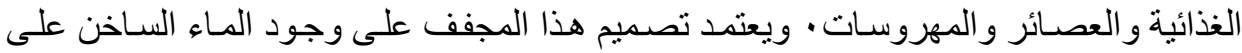

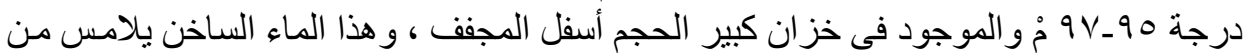

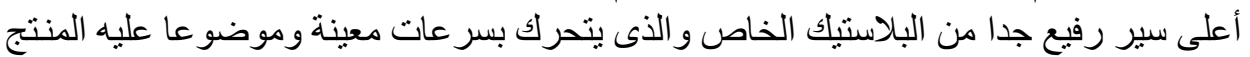
السائل المر اد تجفيفه في دقائق معدودة . البادئ

*مدرس الهندة الزراعية ـ كلية الزراعة ـ جامعة القاهرة 
ويمر هذا السير البلاستيكى على الماء الساخن لتنتقل إليه الحرارة من أسفل و التى تنتقل بدور ها

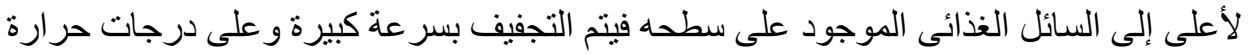

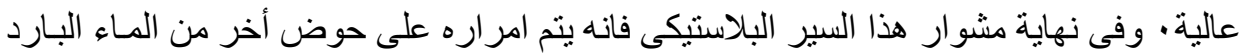

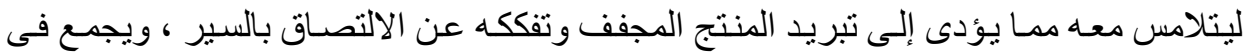

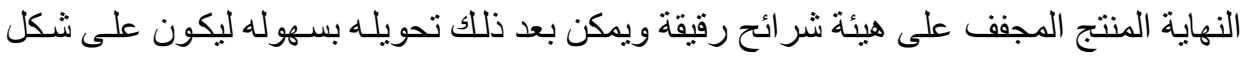
مسحوق ·

وقد اجرى هذا البحث بهدف تصميم نموذج رياضى يمثل الانتقال الحر ارى للوحدة المعملية من

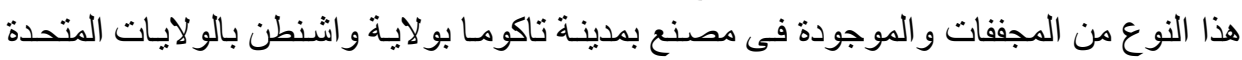

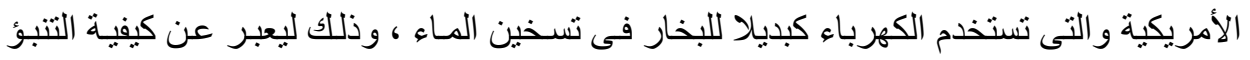

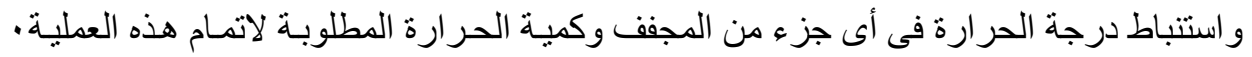

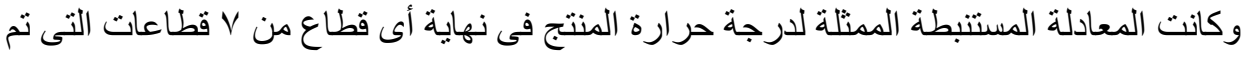

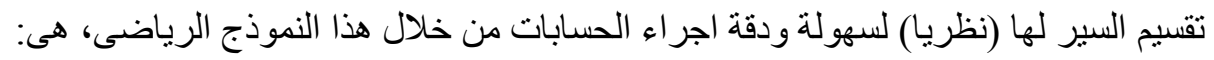
$T_{p, \text { out }}=\left[\left(Q_{p} /\left(\rho_{p} V_{p} c_{p}\right)\right)+\left(T_{p, \text { in }}\right)\right]$

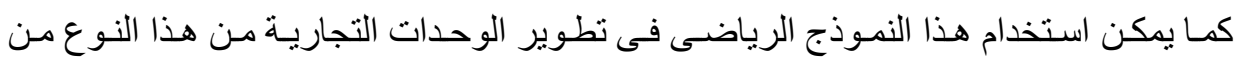

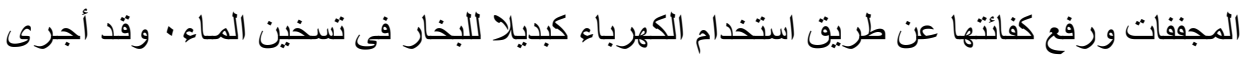

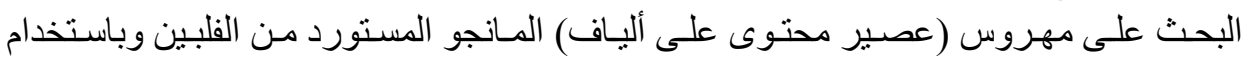

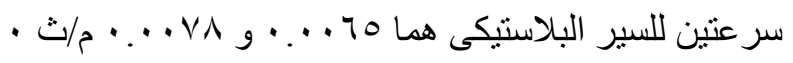
وقد أوضحت نتائج الار اسة ما ليلى: لإنى

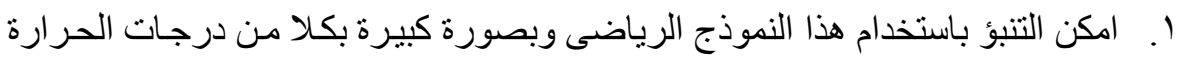

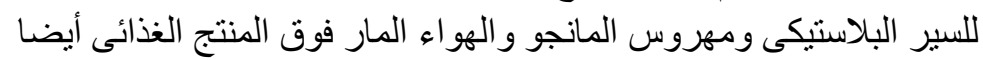

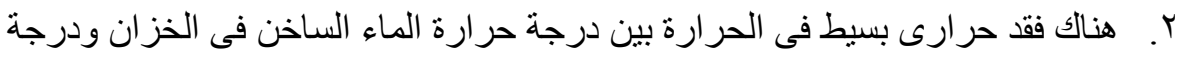

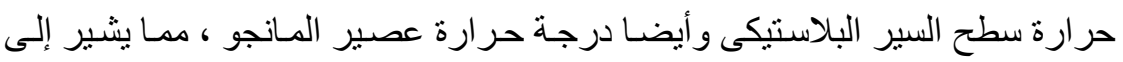

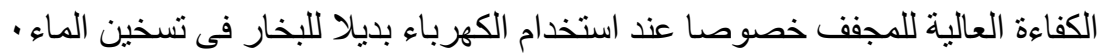

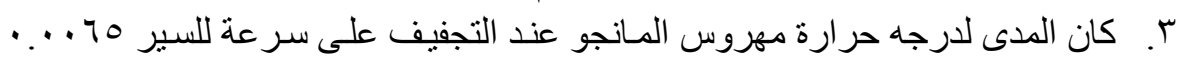

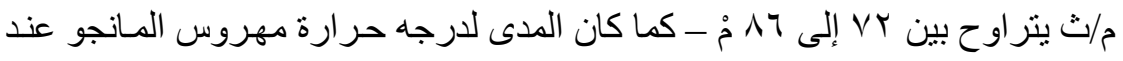

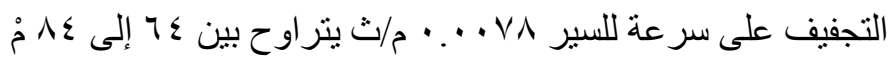

\section{التوصيات}

يمكن استخدام هذا النموذج الرياضى فى استتباط درجة حرارة السير البلاستيكى وأيضا

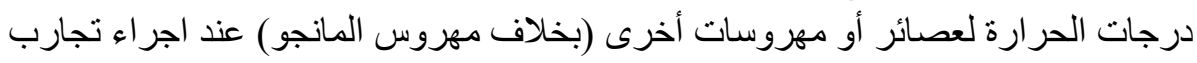

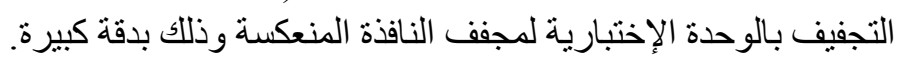

